\title{
GEOLOGICAL CONTRIBUTION TO THE TECTONO- STRATIGRA- PHY OF THE NAFPLION AREA (NW ARGOLIS, GREECE)
}

\author{
Photiades A. \\ Institute of Geology and Mineral Exploration, Olympic Village, 13677 Acharnae, Attica, Greece, \\ fotiadis@igme.gr,
}

\begin{abstract}
The geological mapping in scale 1:5.000 in the greater Nafplion area indicated a Tertiary nappe stack of different Pelagonian-originated tectonic units structurally overlying the Subpelagonian series of Argolis Peninsula.

The Subpelagonian series as lower unit is characterized by a shallow-water carbonate platform of Middle Triassic to Early Jurassic age, locally deep-water ammonitico-rosso facies and red cherts and is overlain by a tectono-sedimentary ophiolitic melange of Malm age. After the compressive tectonic phase of late Jurassic, the Nafplion area at that time records a severe extensional intra-Cretaceous syn-rift phase leading to the deposition of diachronous Meso-autochthonous Cretaceous limestone deposits rich in faulted-derived limestone breccias series, topped by deep-water limestone of Campanian-Maastrichtian and then from Lower Tertiary pelagic limestone facies passes upwards into post-Ypresian flysch.

The different Pelagonian telescoped tectonic units were contemporaneously overthrusting northwestward, over the Subpelagonian post-Ypresian flysch sequence, during the Late Eocene compressive phase, are successively characterized by: (a) a middle tectonic unit of a flyschoidal melange of Late Cretaceous-Early Tertiary age, like the Adheres Melange surfaces in Southern Argolis, associated with various carbonate and ophiolite tectonosomes trapped and carried within this highly disrupted terrigenous flyschoidal melange and, (b) an upper unit consists of Cretaceous carbonate slivers bearing serpentinite sole (Palamidi, Akronafplia, Profitis Ilias, Aria) and/or of Middle Triassic-Early Jurassic carbonate platform slices.
\end{abstract}

The above nappe stacking may be connected with the Eocene continental collision of the Hellenides.

Key words: extensional intra-Cretaceous syn-rift phase, meso-autochthonous series, flyschoidal melange, carbonate outlier, Nafplion, Argolis Greece.

\section{Introduction}

The Argolis peninsula geotectonically belongs to the Pelagonian isopic zone of the Internal Hellenides and forms a composite nappe pile (Bortolotti et al. 2003 and references therein) of several imbricated pre-Neogene tectonic units (Fig.1). However, the transitional paleogeographic environment between the Pindos and the Pelagonian isopic zones, as revealed by the presence of Trapezona and Epidavros Series (Vrielynck, 1978, 1980), places the Argolis peninsula in the Subpelagonian isopic zone (Photiades \& Skourtsis-Coroneou, 1994 and reference therein) and only 
the thick Cretaceous outliers with serpentinite sole, as an Upper tectonic unit, belong to the Pelagonian isopic zone (Photiades, 1986; Mermighis, 1989).

Particularly, the Mesozoic carbonate sequences and the flysch successions in the Nafplion area (Fig. 2a) were interpreted by Tataris et al. (1970) as being continuous stratigraphic sequence successions. However, recognition of various Mesozoic carbonate sequences with flysch differences lead to the realization that the continental collision in this part of the internal Hellenides was a more complex tectono-sedimentary series of events than originally suspected.

The work undertaken was based on large scale (1:5.000) geological mapping covers $50 \mathrm{~km}^{2}$ of the broad area of Nafplion city (Fig. 3), with a view to elucidate the previous geological ambiguities, to reexamine critical contacts of small areas heaving complex boundary conditions, and to establish of its comprehensive tectono-stratigraphy.

\section{Previous investigations and structural setting}

Dercourt (1964) viewed the entire Triassic-Jurassic carbonate formation (Serie de Trapezona) of Argolis as being allochthonous and separated from the Gavrovo-Tripolis zone by high-angle faults. Süsskoch, (1967), Bannert \& Bender (1968) and Bachmann \& Risch (1979) considered the TriassicJurassic carbonate facies differences to reflect basinal and platformal areas within an autochthonous heterogeneous carbonate platform. This kind of carbonate facies differences is being interpreted by Tataris et al. (1970) as a transitional paleogeographic domain between Subpelagonian and Pindos isopic zones. However, Aubouin et al. (1970) placed the Argolis area in Subpelagonian zone.

The Triassic-Liassic deep-water limestones (calcaires d'Epidaure) have been considered by Vrielynck $(1978,1980)$ and Baumgartner (1985) as being allochthonous, tectonically overlying a homogeneous carbonate platform. Moreover, the last author considered these strata to represent the eastern continental margin of the Pelagonian platform and proposed a subsequent emplacement of these deep-water limestones into the platform during Late Jurassic orogenesis. Baumgartner (1985) subdivided further the neritic platform sequences into two units, an external Adhami Basal Sequence and an internal Dhidhymi-Trapezona Basal Sequence distinguished on the basis of overlying ophiolite-derived clastics and an allochthonous ophiolite thrust sheet, which is not found over the external Adhami Basal Sequence, surfaced around Nafplion area and interpreted the above two juxtaposed units as being the result of strike-slip faulting.

The nature of sedimentation changed abruptly in Early Jurassic times with hemipelagic deposition of ammonitico-rosso limestone, interpreted as regional collapse of the platform and continued subsidence giving rise to the accumulation of radiolarian cherts in Middle-Upper Jurassic times (Baumgartner, 1985; Bortolotti et al., 2003).

The obduction of Argolis ophiolitic nappe would originated from Pindos zone (Robertson \& Dixon, 1984; Clift, 1996) or from Vardar zone (Dercourt et al., 1993; Bortolotti et al., 2003; Bortolotti \& Principi, 2005) in late Upper Jurassic time and was manifested by the deposition of ophiolite-derived debris flows and turbidites generated by the advancing thrust sheet of pillow lavas nappe (Baumgartner, 1985; Photiades, 1986; Photiades, 1989; Dostal et al., 1991; Capedri et al., 1996) with TMOR and N-MOR basalts affinities of Triassic to Jurassic ages (Bortolotti et al., 2002, 2003; Saccani et al., 2004).

A hiatus in sedimentation after obduction was succeeded by a diachronous carbonate transgression, over a formerly tectonized sub-marine palaeorelief where the Meso-autochthonous sedimentary se- 


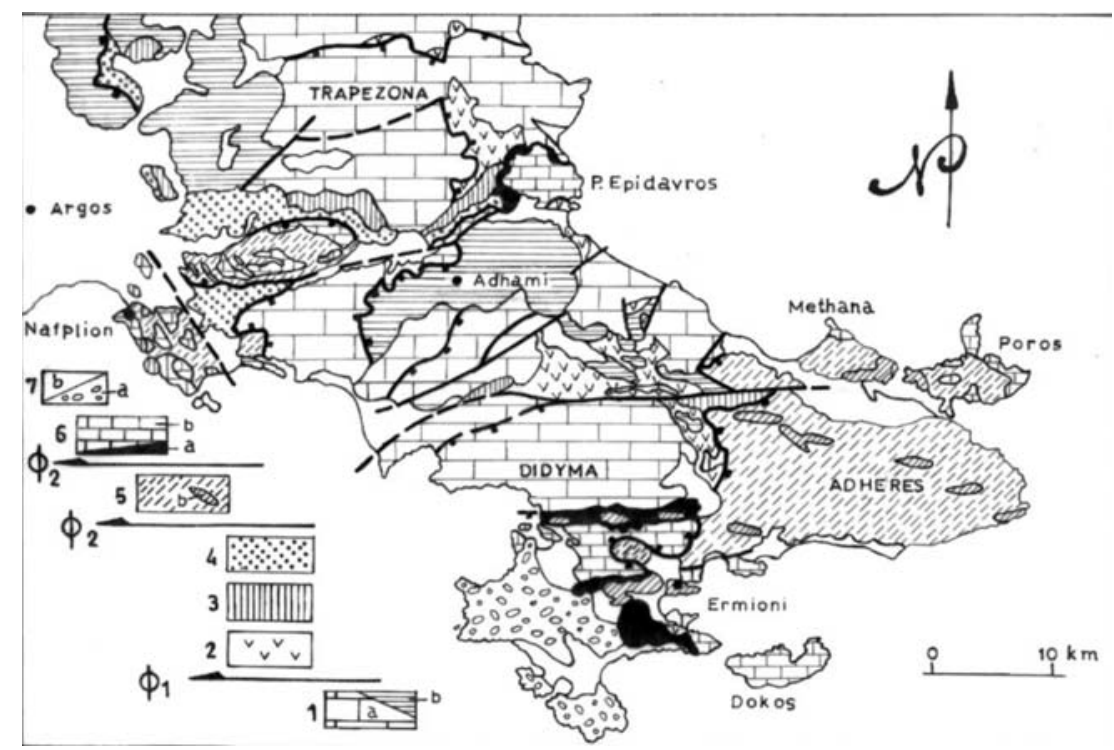

Fig. 1: Geological simplified map of Argolis. Modified from Bortolotti et al. (2003). 1: Triassic-Jurassic shallow-water limestone (a), Triassic-Jurassic hemipelagic limestone (b), 2: pillow-lava ophiolite nappe, 3: Mesoautochthonous series with Cretaceous - Lower Eocene carbonate, 4: post-Ypresian flysch, 5: flyschoidal melange (a) with hemipelagic limestone (b), 6: Cretaceous limestone (b) with serpentinite (a), 7: Upper Miocene to Pliocene sediments (a) and Quaternary sediments (b), $\Phi 1$ : late Jurassic tectonic phase and $\Phi 2$ : late Eocene tectonic phase.

quence of Argolis has been deposited giving rise to the Ligourio, Stamateika, Agios Dimitrios, Midhea-Manesi, Kandhia, Karnazeika, Stavropodi and Mataranga members, which began in the Upper Jurassic age and continued into the Lower Eocene age (Tataris et al., 1970; Vrielynck, 1978, 1982; Bannert et al., 1984; Baumgartner 1985; Photiades \& Skourtsis-Coroneou, 1994; Bortolotti et al., 2003). The beginning of the deposition was diachronous. The sequence in its maximum development includes Albian to Cenomanian neritic limestone. The subsidence of the platform is recorded from Turonian times when rapid deepening of the carbonate facies and intra-platform faulting occurred which is characterized by faulted-derived breccias rich in basaltic and red chert clasts, cemented by Campanian-Maastrichtian pink hemipelagic limestone, deposited during this episode, and then from Paleocene up to the Lower-Middle Eocene pelagic to reefal limestone facies passes upwards into post-Ypresian flysch. Events of emergence associated with intensive erosion- with several hiatustook place during the Late Cenomanian-Early Senonian and the Late Maastrichtian-Palaeocene (Photiades and Skourtsis-Coroneou 1994).

Tectonically upwards in south, central and northwestern parts of Argolis Peninsula several thrust sheets are dominated and structured, from the base to the top, by a prominent flyschoidal melange or Adheres melange after Bortolotti et al. (2003), which is not organised formation and is developed as an intensively deformed arenaceous flysch including blocks of several lithologies. This flyschoidal melange is described as Ermioni Complex after Robertson et al. (1987) and contains various tectonosomes of Mid-Upper Jurassic granodiorite associated with Upper Jurassic limestone (Photiades \& Keay, 2000), andesitic volcanic to pyroclastic rocks (Sideris et al., 1987), bearing tectonic slivers of MOR basalts (Robertson et al., 1987; Clift, 1996) of Upper Jurassic age (Bortolotti et al., 2003), ser- 
pentinite and pelagic limestone of Campanian-Maastrichtian. Moreover, the flyschoidal melange is locally associated with a deep-water limestone of Aptian-Maastrichtian age (Clift and Robertson, 1990b), and passes conformably upwards into calcareous and terrigenous turbiditic flysch deposits of Maastrichtian - Paleogene age (Susskoch et al., 1984), Paleocene and Paleocene-Eocene ages (Christodoulou, 1972; Bachmann \& Risch, 1979). However, Clift (1996) agrees with the data of Bachmann \& Risch (1979) and Bortolotti et al. (2003) found a Late Cretaceous age (probably Campanian).

Finally, the flyschoidal melange is tectonically overlain by an Upper tectonic Unit (Photiades, 1986; Mermighis, 1989) or Faniskos Unit (Bortolotti et al., 2003), which consists of schistose serpentinized harzburgite tectonic "melange" including various boninitic and metamorphic rocks (Photiades 1986, Dostal et al., 1991; Saccani \& Photiades, 2005), and is overlain upwards by several transgressed shallow-water carbonate sequences of (a) Kimmeridgian-Portlandian age (Decrouez et al., 1983; Tsaila-Monopolis et al., 1992), (b) via a conglomeratic and/or a lateritic episode by a thick neritic Cretaceous limestone sequences, range from Barremian to Turonian, topped by reddish hemipelagic limestone of Middle Maastrichtian age (Akros formation, Palamidi formation and Faniskos formation; Fourni formation; Decrouez 1976, 1977 a, b; Charvet et al., 1976; Philip et al. 1989; Gaitanakis and Photiades, 1993; Photiades and Skourtsis-Coroneou 1994; Gaitanakis et al. 2007) and, also (c) of deep-water limestones of Aptian-Maastrichtian age (Decrouez 1976, 1977c; Clift \& Robertson, 1990b; Gaitanakis et al. 2007) pass up rapidly into terrigenous flysch of MiddleUpper Maastrichtian age (Mermighis, 1989).

On the other hand, Clift \& Robertson (1990a, b) affirm that all the Mesozoic platform carbonate units and their overriding thrust sheets form part of a single tectonostratigraphic succession of Pelagonian zone. Later, Clift (1996) modified the previous scheme as regards to the Adheres area where Triassic-Jurassic carbonate unit with its ophiolitic Upper Jurassic melange are "conformably and uncomformably" overlain by the Akros Formation platform and basin carbonate facies and then by the "turbiditic flysch of the Ermioni Complex" (also the Cretaceous slope limestones of the Poros Formation would be the base of the Ermioni Complex).

\section{Tectono-stratigraphy}

\section{Observations}

In the study area, Tataris et al. (1970) show that over a unique and undifferentiated Tertiary siliceous turbiditic flysch sequence (Fig. 2a), which is floored by a single continuous Cretaceous sequence (Palamidi, Akronafplia, Aria, Karathonas), is consistently thrust by sheets of Triassic-Jurassic limestones and assigned them as cherty deep-water carbonates originated from the para-autochthonous Triassic-Jurassic limestones sequence.

Remapping of this area shows (Fig. 2b and 3), however that this Tertiary siliceous turbiditic flysch sequence (coded as fg1 in Fig. 3) appears to a great extent in the NE part of Lefkakia area. At this outcrop the flysch is highly cemented, thin-medium bedded, coarse-fine grained sandstone turbidites, dominated by polycrystalline quartz debris. The source terrain of the flysch is obviously to be the metamorphic basement of the Pelagonian zone, lying to the northeast, as the only known source for the abundant polycrystalline quartz. The total thickness of the flysch around Nafplion is given by proposed cross-section (Fig. 3, C) where must be an underlying concealed sequence of Karathonas limestone (coded as Ki-s.c and Ks.k1 in Fig. 3), the ophiolitic-derived clastic formation (coded as Jm-s.mg) and the basement with Triassic-Liassic Trapezona platform (coded as Ts-Ji.k,d).

The widespread ophiolite-derived clastics of Malm age (Baumgrtner, 1985; Bortolotti et al., 2003 


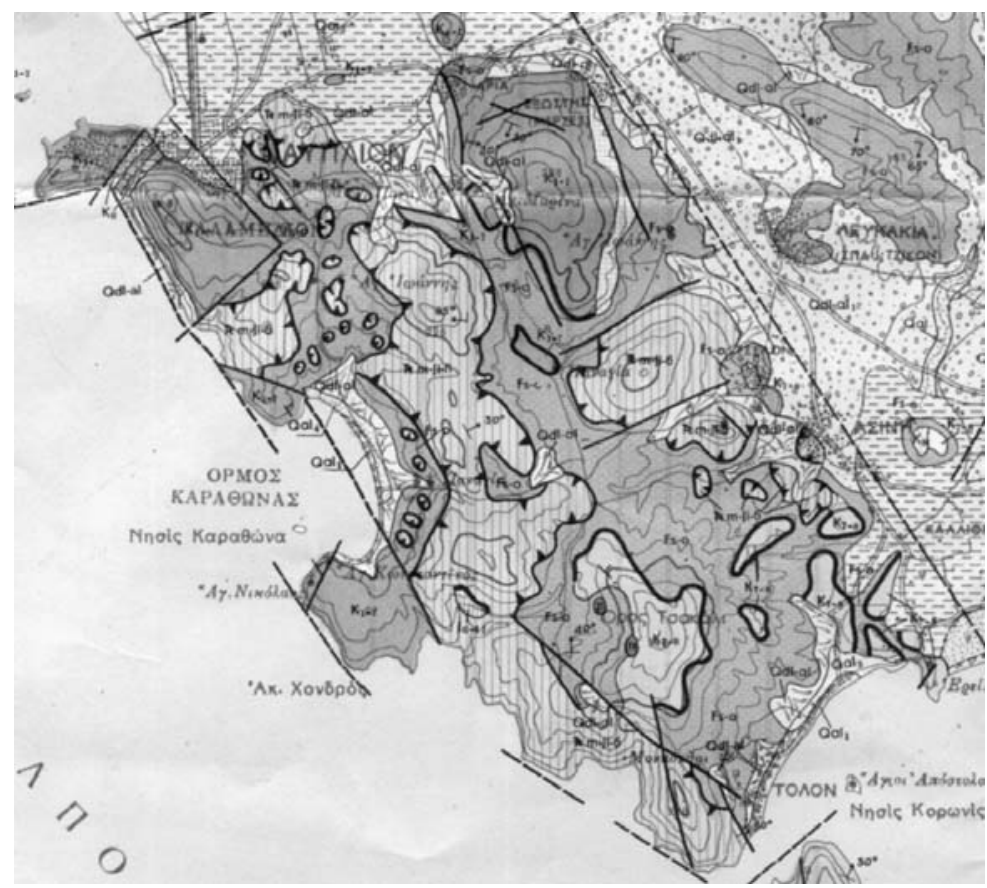

Fig. 2a: Extracted geological part from geological map of Nafplion sheet in scale 1:50.000 (Tataris et al., 1970). Undivided Tertiary siliceous turbiditic flysch (fs-o), Cretaceous sequence (K1-7, K7-8), serpentinite $(\pi)$ and Middle Triassic-Liassic bearing chert limestone (Tm-Ji-6).

and references therein), outcrop as tectono-sedimentary ophiolitic melange succession, lie above the drowned platform sequence of the Trapezona, which appears at the western and northern parts (between Palamidi and Aria mountains) of the study area (Fig. 2b, sections a, c).

The Karathonas limestone sequence (northern and southern parts of Karathonas bay) of Cretaceouslower Eocene age is unconformably developed over the ophiolitic-derived clastic formation and the basement of Triassic-Liassic Trapezona platform (Fig. 2b, sections c, d). The Karathonas limestone sequence is a coarse calcareous dominated conglomerate, cemented in a matrix of reddish micritic limestone, provided by shallow-water fault limestone breccias, whilst more thickly bedded, redeposited limestones replace shallow-water packstones. They show evidence of a sharp increase subsidence and intra-platform faulting in Turonian time marked by interval of breccias and can be related of regional extension at this time. Above this level the facies deepen markedly so that pink to reddish hemipelagic limestones of Campanian-Maastrichtian to Paleocene age and flysch (coded as fg1 in Fig. 3) sequences are found (at the northward contact-base of the Akronafplia peninsular hill leading to the Nafplion city and at the contact-base between Akronafplia and Palamidi mountains).

Locally, the previous breccias are also developed up to Lower Eocene shallow-water limestone (like Agios Dimitrios and Midea-Manesi formations by Tataris et al., 1970; Vrielynck 1982; or at Anastassopouleika area (Ligourio) and then pass up to a post-Ypresian flysch sequence (Photiades \& Skourtsis-Coroneou, 1994). Bachmann \& Risch (1979) have been documented Paleocene to Eocene ages within the clastics and Bortolotti et al. (2003) have been assigned an Upper Paleocene age within reddish marls at the basal part of the flysch sequence. 

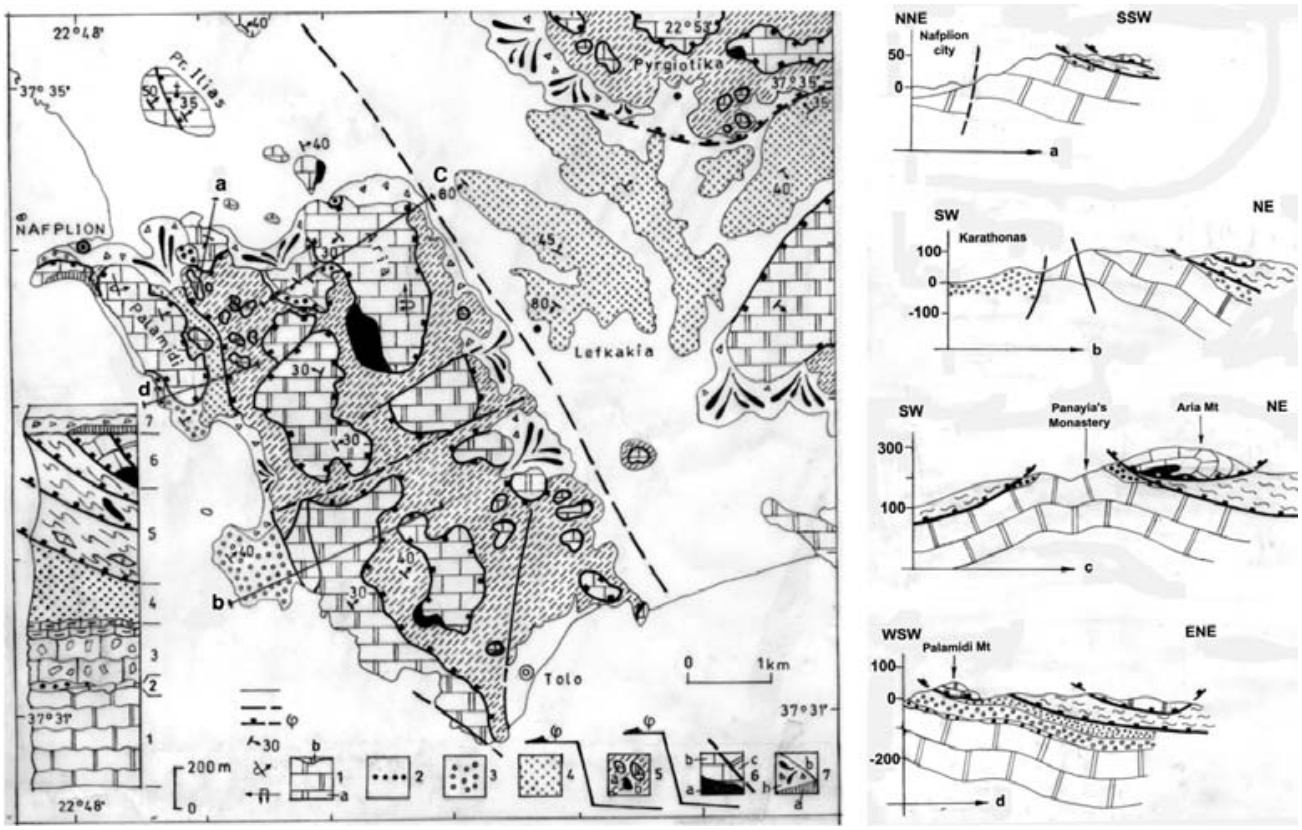

Fig. 2b: Geological simplified map (Photiades \& Mitropoulos, in press), tectono-stratigraphic column and schematic cross-sections ( $\mathrm{a}, \mathrm{b}, \mathrm{c}$ and d) of the greater Nafplion area. Lower Unit, 1: Triassic-Jurassic shallowwater limestone (a) with ammonitico-rosso (b), 2: tectono-sedimentary ophiolitic melange, 3: Meso-autochthonous series with Upper Cretaceous - Lower Eocene carbonates, 4: post-Ypresian flysch; Middle Unit, 5: flyschoidal melange complex with Cretaceous carbonate (a), Triassic carbonate (b) and serpentinite (c) tectonosomes, Upper Unit, 6: Cretaceous (b) and Triassic (c) carbonate outliers with serpentinite (a) sole, 7: Tyrrhenian deposits (a), Quaternary sediments (b) and $\phi$ : late Eocene tectonic phase.

The Triassic-Liassic Trapezona platform, the ophiolitic-derived clastic formation, the unconformably Karathonas limestone sequence with flysch succession belong to the Subpelagonian domain of Argolis (Photiades \& Skourtsis-Coroneou, 1994 and references therein).

On the other hand, the SW and NE (Pyrgiotika) areas (Fig. 2b, 3A) are exclusively composed by a tectonically highly disrupted flysch bearing ophiolitic blocks that may represent a remnant of flyschoidal melange (coded as fl-mg in Fig. 3). More precisely, the flyschoidal melange is composed as marly terrigenous poorly cemented turbiditic flysch, which is mostly composed of sheared debris flow rich of ophiolitic debris, like red chert, basalt and serpentinite, of reworked sandstone debris flow and of various Cretaceous limestone breccias. Bortolotti et al. (2003) found a Late Cretaceous age (probably Campanian) for the Adheres melange surfaces in southeast Argolis.

The Tertiary overriding thrust plane, of the flyschoidal melange above the siliceous turbiditic flysch sequence, has cut strongly down sequence into the Trapezona sequence and could be also represented as out of sequence thrusting, due to the already complicate uplifting of the Subpelagonian Meso-autochthonous series of Argolis, before this Tertiary folding and thrusting of the Pelagonianderived flyschoidal melange associated with Upper tectonic unit.

Furthermore, the flyschoidal melange of Nafplion area is tectonically overlain by Cretaceous limestone klippens and Triassic-Jurassic limestone slivers. 

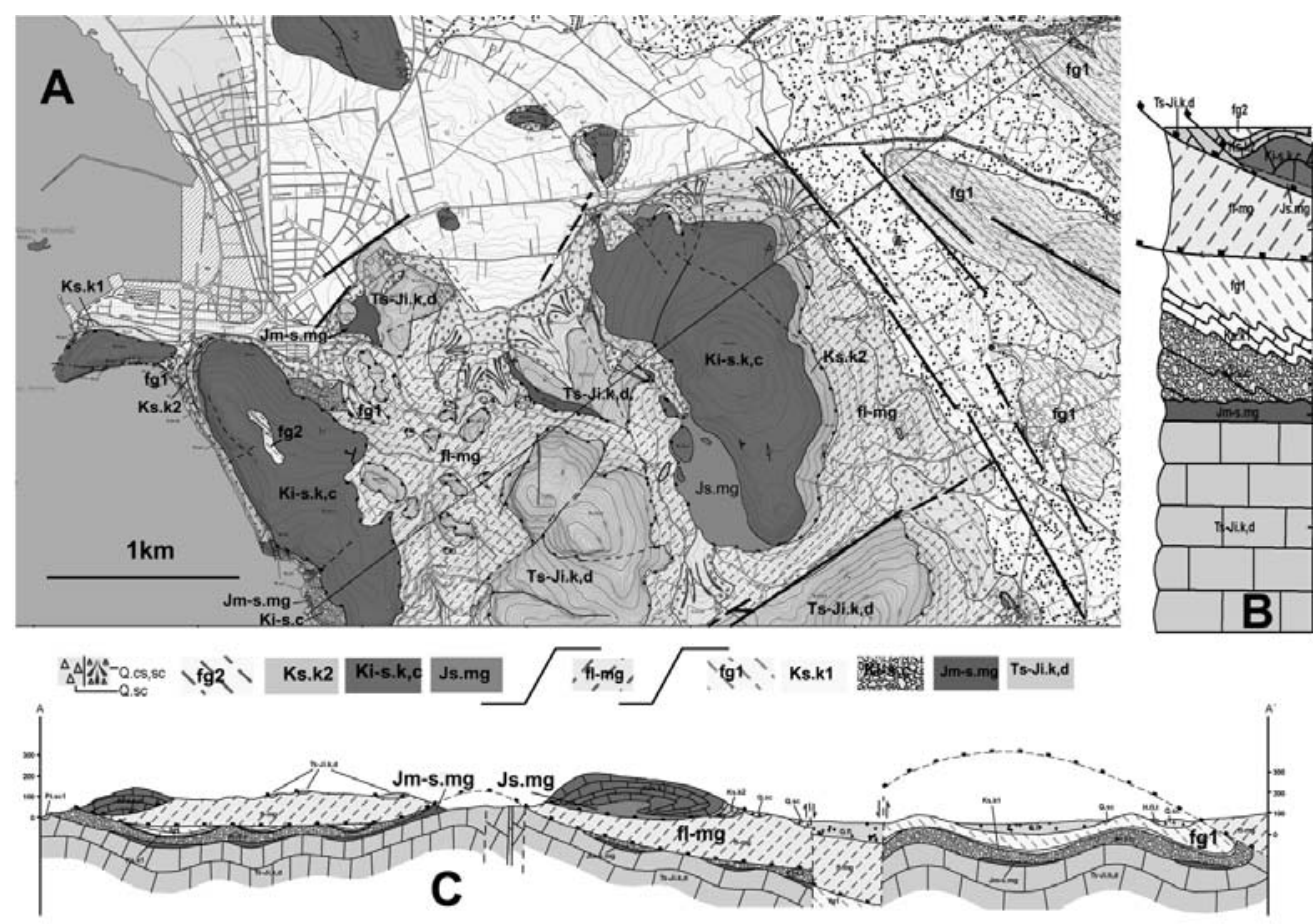

Fig. 3: Geological map (A), tectono-stratigraphic column (B) and geological section (C) of the greater Nafplion area. Lower Unit, Triassic-Jurassic shallow-water carbonate (Ts-Ji.k,d), tectono-sedimentary ophiolitic melange (Jm-s.mg), Meso-autochthonous series with Cretaceous carbonates (Ki-s.c \& Ks.k1), post-Ypresian flysch (fg1); Middle Unit, flyschoidal melange complex (fl-mg), probably of Upper Cretaceous age; Upper Unit, serpentinite sole (Js.mg), Triassic-Jurassic carbonate outlier (Ts-Ji.k,d), Cretaceous carbonate outlier (Ki-s.k,c \& Ks.k2) with post-Upper Cretaceous flysch (fg2) and late Eocene tectonic phase.

The outcrops of various tectonic sized slices are composed of shallow-water limestone of TriassicJurassic age (coded as Ts-Ji.k,d in Fig. 3) that also crops out as basement too and of several tectonosomes of Cretaceous limestone (coded as Ki-s.k,c and Ks.k2 in Fig. 3) bearing serpentinite sole (coded as Js.mg) (Akronafplia, Palamidi and Aria mountains) and confirm that their thrusting was obviously from southeast to northwest and overthrusting also the Pindos flysch in the Argos Castle area that consists of Cretaceous outlier with serpentinite sole too.

The carbonate Cretaceous sequence exposures of the Akronafplia, Palamidi, and Aria Mountains and of several hillocks around Nafplion, such as Profitis Ilias, are clearly thrust sheets or klippens, which lie over the flyschoidal melange. At the base of western part contact-base of Aria massif, a several mthick conglomeratic formation, including abundant serpentinite and Kimmeridgian neritic clasts, is clearly exposed over serpentinites. Analogous transgressional event is also signalized by Cayeux (1904). Clasts of ophiolitic material are well-rounded in upwards carbonate Barremian sequences. These carbonate Cretaceous sequences are typically massive, thick-bedded bioclastic rocks, suggesting accumulation in a quiet shelf environment from Barremian to pre-Turonian, until a rapid transition to pelagic micrites of Campanian-Maastrichtian age (Dercourt, 1964; Decrouez 1977a, b) towards the top of the section and then pass to post-Maastrichtian calcarenites to marly terrigenous poorly cemented turbiditic flysch, as remnant at the top of Palamidi mountain (coded as fg2 in Fig. 3). 
These slices are considered as an Upper tectonic unit originated from the Pelagonian domain (Photiades, 1986; Mermighis, 1989) and are structurally overlying the flyschoidal melange (Bortolotti et al., 2003). Apparently, the flyschoidal melange reached the Nafplion area, shedding debris onto this frontal thrust area, extending from Nafplion to Ligourio depression, but also northward to Tyrintha depression plain outlined in its central part by several Cretaceous age hillocks such as the Prophitis Ilias.

\section{Synthesis}

The resulted tectono-stratigraphy of Nafplion area is schematically illustrated in Figures $2 \mathrm{~b}$ and 3 and comprises the para- and meso-autochthonous Mesozoic series and post-Ypresian flysch of Argolis that belong to the Subpelagonian domain (Aubouin et al., 1970; Photiades et Skourtsis-Coroneou, 1994 and references therein), which is overlapping by a tectonic flyschoidal melange of probably Late Cretaceous age, like Adheres melange (Bortolotti et al., 2003), as Middle tectonic Unit, and finally at top by Cretaceous and/or Triassic limestone outliers with serpentinite sole as Upper Unit originated from Pelagonian domain (Photiades, 1986; Mermighis, 1989). These units were tectonically piled up during the late Eocene or post-flysch compressive period that challenged the whole Pelagonian and Subpelagonian domains (Vrielynck, 1982; Photiades, 1986; Photiades \& Karfakis, 1998; Bortolotti et al., 2003).

The three pre-Neogene tectonic units (Fig.3) are from the base to the top as follow:

\subsection{Lower Unit}

The Lower Unit (Fig. 3A-B) comprises a Middle Triassic to Early Jurassic massively bedded, shallow-water carbonate (Trapezona or Didyma-Trapezona) platform, which is locally followed upwards by condensed reddish nodular pelagic limestones of Toarcian-Bathonian age (Bachmann \& Risch, 1979) and is pursued with reddish brown thin-bedded ribbon siliceous mudstones and radiolarian cherts (20-50m thick) of Oxfordian-Kimmeridgian age (Baumgartner 1985; Bortolotti et al. 2003). These deep-sea sediments are generally interpreted to be a reflection of drowning of the platform, and the siliceous sediments are successively developed upwards by a tectono-sedimentary ophiolitic melange succession of Malm age. The ophiolitic melange consists of turbiditic sorted layers of fine-grained distal detritic ophiolitic sediments (5-50m thick) alternating with sorted layers rich in ophiolitic clasts, in addition to thin layers of Kimmeridgian-Tithonian radiolarites. This sequence is followed upward by ophiolitic olistostromes (5-50m in thickness) containing rounded fragments (up to $50 \mathrm{~cm}$ in diameter) of boninitic lavas and coarse-grained boninitic-type rocks set in arenitic matrix of various ophiolitic clasts and fragments originated from the underlying limestones and radiolarian cherts. The boninitic lavas and coarse-grained boninitic-type considered to be generated in supra-subduction setting (Photiades 1986; Dostal et al. 1991; Capedri et al. 1996). The presence of such deposit records the paroxysmal tectono-sedimentary events due to early compressional late Jurassic tectonic phase, affecting synchronously the oceanic basin and the Subpelagonian continental margin (Photiades, 1986; Dostal et al. 1991; Capedri et al. 1996; Bortolotti et al., 2003).

The above para-autochthonous succession, in Nafplion area, has undergone during the Cretaceous time important erosion episodes, following by unconformably transgressive deposition of the Cretaceous-Lower Tertiary carbonate sequences (Meso-autochthonous Series), which pass up to a typical post-Ypresian flysch of Argolis (Vrielynck 1981; Photiades 1986; Photiades \& Skourtsis-Coroneou 1994; Bortolotti et al., 2003).

A roughly up to $100 \mathrm{~m}$ thick Cretaceous to lower Eocene sequence, at Karathonas bay and around 
Palamidi and Arvanitia (Akronafplia) foothills, consists of interbedded pelagic limestones, cherts and coarse polymict carbonate breccias sequence including ophiolitic fragments (mainly basalt and serpentinite) and shallow water limestones derived from the below deeply altered and fractured Early Jurassic shallow-water carbonate platform. This coarse ophiolite-carbonate breccias sequence succession evolving progressively into pink and red pelagic limestone rich in Globotruncanidae of Upper Cretaceous - Paleocene age, follows up with the red mudstones of Upper Paleocene age (Bachmann \& Risch, 1979; Bortolotti et al., 2003) and then from marly-sandstone to quartz-rich sandstone flysch sequences of post-Ypresian age (Photiades \& Skourtsis-Coroneou, 1994).

Furthermore, the coarse polymict carbonate breccias of the Mesoautochthonous Series is interpreted as a channel or canyon fill in a pelagic environment and attests the fact that the ophiolite nappe in the greater area of Nafplion has been completely eroded due to the Cretaceous syn-tectonic events activated by Mesozoic extensional faults (see Fig. 2, like NE-SW Lefkakia graben faulted area). On the contrary, in the eastern and central Argolis areas, the pillow-lavas-bearing ophiolite nappe surfaces and is also unconformably overlain by several heterogeneous Cretaceous series, as well as by post-Ypresian flysch (Photiades 1986; Photiades \& Skourtsis-Coroneou 1994).

\subsection{The Middle Unit with a tectonic flyschoidal mélange}

The Middle Unit (Fig. 3A-B) consists of a tectonic flyschoidal melange (see Fig. 2b, Pyrgiotika area), which tectonically emplaced above the Meso-autochthonous Series of greater Nafplion area and drifted slices and or/ tectonosomes, originated both from continental and oceanic environment, within a flyschoidal matrix. The flyschoidal melange originated by the tectonic accretion of the innermost exposed Pelagonian continental margin during the late Eocene continental collision of the Hellenides (Bortolotti et al., 2003 and references therein).

Nevertheless, the flyschoidal melange that developed during the Eocene ensialic tectonic phase tectonically overlies the Meso-autochthonous Series (Bachmann \& Risch, 1979; Bortolotti et al., 2003) in central-east Argolis and mainly surfaces in southern Argolis, known as Adheres melanges (see Fig.1), which is characterized by a disrupted turbiditic succession of siltstones, sandstones and marls affected by strong pervasive deformations. Bortolotti et al. (2003) suggest an Upper Cretaceous (Campanian) age for this melange, and Bachmann \& Risch (1979) propose an Eocene age formation. However, Clift \& Robertson (1990b) and Clift (1996) named the above melange as Ermioni Complex and consider that is deposited over the ophiolite.

Besides, this melange incorporates blocks of various natures, including Triassic volcanics, MiddleLate Jurassic radiolarites, Jurassic and Cretaceous limestones, andesites, Jurassic granodiorite, serpentinites and various basalts, originated from the Pelagonian continental margin and the Vardar Ocean (Bortolotti et al., 2003 and references therein).

\subsection{Upper Unit with Cretaceous and/or Triassic limestone outliers}

An Upper Unit (Fig. 3A-B) emplaced tectonically over the previous ones and synchronously thrust over the flyschoidal melange, and is composed, at the base, by a schistose serpentinite tectonic sole (up to $100 \mathrm{~m}$ thick) bearing meter-sized, lens-shaped blocks of basalts, boninitic rocks (Capedri et $a l ., 1996)$ and various exotic blocks (Photiades, 1986) and, at the top, by an unconformably Cretaceous carbonate sequence cover (up to $350 \mathrm{~m}$ thick). Furthermore, several Cretaceous limestone (Dercourt, 1964; Decrouez, 1977a, b) outliers such as Palamidi, covered with apparently post-Upper Cretaceous flysch, Akronafplia, Profitis Ilias and Aria with serpentinite tectonic sole, as well as 
tectonosomes and/or megablocks of Triassic- Liassic carbonates detached from the shallow-water carbonate sequence of the Subpelagonian Lower Unit and are overthrust the flyschoidal melange (Fig. 3C).

The Upper unit tectonically overlies the post-Ypresian flysch of the Meso-autochthonous series in eastern and central Argolis, as well as the Adheres mélange in south Argolis, where is also tectonically overlain by Kimmeridgian-Maastrichtian carbonate slices of the Upper unit, which are covered, in turn, by a post-Upper Cretaceous flysch.

\section{Discussion-Conclusion}

The Nafplion area is built by Upper Triassic to Lower Jurassic platform limestone and this series overthrust during the late Jurassic by pillow-lava ophiolite nappe and then the area turned into deeply eroded during Cretaceous times. Upper Cretaceous pelagic and coarse clastic sediments breccias rich in basalts, serpentinites and shallow-water limestones record the important extensional intra-Cretaceous syn-rift phase which affects the Argolis peninsula. These sediments unconformably overlie the Upper Triassic to Lower Jurassic platform limestone and certify the ongoing erosion of the pillow-lavas ophiolite nappe in a high-relief, deeper marine environment.

These Meso-autochthonous series with detrital levels are evolved progressively into pink and red pelagic limestone of Upper Cretaceous. Up section follow of Paleocene limestone interbeds, which are in turn conformably covered by post-Ypresian flysch.

However, the imbricated pre-Neogene stacking units of greater Nafplion area have been caused by the northwestward post-flysch overthrusting of the flyschoidal melange and of the Upper unit over the previous para- and meso-autochthonous Subpelagonian series.

The flyschoidal melange and the overriding Upper tectonic unit could be interpreted as thrust sheet units that record the collapse of the Pelagonian continental margin and Vardar Ocean (Bortolotti et al., 2003), and were contemporaneously thrusting northwestward over the post-Ypresian flysch of the meso-autochthonous Subpelagonian series of Argolis Peninsula (Photiades \& Skourtsis-Coroneou, 1994; Photiades \& Karfakis, 1998).

This post-flysch tectonic phase, of significant geodynamic importance may be connected to the continental collision between Internal and External Hellenides and to the associated Cycladic blueschist belt formation, during the Eocene (Jolivet \& Brun, 2010) and leading during the late Eocene to the tectonic accretion of the Subpelagonian and Pelagonian isopic zones in Argolis Peninsula.

Flyschoidal melange and Upper tectonic unit could be interpreted as thrust sheet units, telescoped from Vardar and Pelagonian Zones, towards the northwestern onto the Subpelagonian Meso-autochthonous series of Argolis.

\section{References}

Aubouin J., Bonneau M., Celet P., Charvet J., Clement B., Degardin J.M., Dercourt J., Ferrière J., Fleury J.J., Guernet C., Maillot H., Mania J.H., Mansy J.L., Terry J., Thiebault P., Tsoflias P. and Verrieux J.J., 1970. Contribution à la géologie des Hellénides: le Gavrovo, le Pinde et la zone ophiolitique subpélagonienne. Ann. Soc. Géol. Nord, 90: 277-306.

Bachmann, G.H. and Risch, H., 1979. Die geologische Entwicklung der Argolis-Halbinsel (Peloponnes, Griechenland). Geol. Jb., B32: 3-177.

Bannert, D. and Bender, H., 1968. Zur Geologie der Argolis-Halbinsel (Peloponnes, Griechenland). Ge- 
ological et Palaeontologica, 2, 151-162.

Bannert, D., Kalkreuth, W., Wallner, P., Risch, H. and Bachmann, G.H., 1984. Ligourion sheet in scale 1:50.000, Geological map of Greece. Institute of Geology and Mineral Exploration, Athens 1984, Greece.

Baumgartner, P.O., 1985. Jurassic sedimentary evolution and nappe emplacement in the Argolis Peninsula (Peloponnesus, Greece). Mém. Soc. Helv. Sci. Nat. 99: 1-111.

Bortolotti, V., Carras, N, Chiari, M., Fazzuoli, M., Marcucci, M., Photiades, A. and Principi, G., 2002. New geological observations and biostratigraphic data on the Argolis Peninsula: palaeogeographic and geodynamic. Ofioliti, 2002, 27 (1), 43-46 43.

Bortolotti, V., Carras, N, Chiari, M., Fazzuoli, M., Marcucci, M., Photiades, A. and Principi, G., 2003. The Argolis Peninsula in the palaeogeographic and geodynamic frame of the Hellenides. Ofioliti, 28/2, 7994.

Bortolotti, V. and Principi, G., 2005. Tethyan ophiolites and Pangea break-up. The Island Arc 14, 442470.

Capedri, S., Grandi, R., Photiades, A. and Toscani, L., 1996. "Boninitic" clasts from the Mesozoic olistostrome and turbidites of Angelokastron (Argolis, Greece). Geological Journal, vol. 31, 301-322.

Cayeux, L., 1904. Géologie des environs de Nauplie. Existence du Jurassique supérieur et de l'Infracretace en Argolide (Grèce). Bull. Soc. Geol. France, (4), 4, 87-105.

Charvet J., Décrouez D. and Polsak A., 1976. Le Crétacé du Faniskos (Argolide, Grèce). Examen paléontologique, répercussions stratigraphiques, paléogéo-graphiques et tectoniques. Arch. Sci. Genève, 29 (3): 247-258.

Christodoulou G., 1972. The age of some formations of the Poros Island (Argolis, E. Peloponnesos), and their tectonical relation. Bull. Geol. Soc. Greece, 8 (2): 163-180.

Clift, P.D., 1996. Accretion tectonics of the Neotethyan Ermioni Complex, Peloponnesos, Greece. J. Geol. Soc. London, 153, 745-757.

Clift, P.D. and Robertson, A.H.F., 1990a. Deep-water basins within the Mesozoic carbonate platform of Argolis, Greece. J. Geol. Soc. London, 147, 825-836.

Clift, P.D. and Robertson, A.H.F., 1990b. A Cretaceous Neo-Tethyan carbonate margin in Argolis, southern Greece. Geol. Mag., 127: 299-308.

Decrouez, D., 1976. Étude stratigraphique et micropaléontologique du Crétacé d'Argolide (Péloponnèse, Grèce). Thèse Univ. de Genève, Suisse, 157pp.

Decrouez, D., 1977a. Etude stratigraphique du Cretace d'Argolide (Peloponnese septentrional, Grece). 1Introduction generale et la formation de l'Akros (domaine ophiolitique externe). Notes Lab. Paleont. Univ. Geneve, (3): 1-8.

Decrouez, D., 1977b. Etude stratigraphique du Cretace d'Argolide (Peloponnese septentrional, Grece). La formation de la Palamede, Sous zone de Trapezona. Notes Lab. Paleont. Univ. Geneve, (4): 1-6.

Decrouez, D., 1977c. Étude stratigraphique du Crétacé d' Argolide (Péloponnèse septentrional, Grèce). 3- La Série du Cap Kastri en Argolide méridionale et conclusions générales. Note du Laboratoire de Paléontologie de l' Université de Genève, Fascicule, $N^{\circ}$ 5, 1-4.

Decrouez, D., Conrad, M.A. and Vrielynck, B., 1983. Sur la présence de calcaires d'âge jurassique supérieur en Argolide méridionale (Péloponnèse, Grèce). Eclogae Geologicae Helvetiae, 76/2, p. 317 325 .

Dercourt, J., 1964. Contribution à l'étude géologique d'un secteur du Péloponnèse septentrional. Annales Géologiques des Pays Helléniques, 15, 1-417.

Dercourt, J., Ricou, L.E. and Vrielynck, B., 1993 (Eds.), Atlas Tethys palaeoenvironmental maps. Gau- 
thier-Villars, Paris, 307 pp.

Dostal, J., Toscani, L., Photiades, A. and Capedri, S., 1991. Geochemistry and petrogenesis of Tethyan ophiolites from Northern Argolis (Peloponnesus, Greece). European Journal of Mineralogy, vol. 3, 105-121.

Philip, J., Mermighis, A. \& Tronchetti, G., 1989. Nouvelles données stratigraphique et paléogéographiques sur le Crétacé supérieur de domaine Hellénique interne. Le Massif de l'Akros (Argolide, Grèce). C. R. Acad.Sci.Paris, 308, 1379-1384.

Gaitanakis, P. and Photiades, A., 1993. New data on the geology of Southern Argolis (Peloponnesus, Greece). Bull. Geol. Soc. Greece, 28 (1): 247-267.

Gaitanakis, P., Photiades, A., Tsaila-Monopolis, S. and Tsapralis, V., 2007. Geological map of Greece in scale 1:50.000 "KRANIDI-SPETSES sheet". Athens Institute of Geology and Mineral Exploration.

Jolivet, L. and Brun, J-P., 2010. Cenozoic geodynamic evolution of the Aegean. Int J Earth Sci (Geol. Rundsch.) 99:109-138.

Mermighis, A., 1989. Plates-formes carbonatées et récifs à rudistes du Crétacé supérieur de l'Argolide septentrionale (Péloponnèse NE, Grèce). Thèse Univérsité de Provence, 171p.

Photiades, A.D., 1986. Contribution a l'etude geologique et metallogenique des unites ophiolitiques de l'Argolide septentrionale (Grece). These de Doctorat de $3^{e}$ cycle, Universite de Franche - Comte (Besancon), $n^{0}$ 499, 261p.

Photiades, A., 1989. The diversity of Jurassic volcanism in the inner parts of the Hellenides: The Northern Argolis ophiolitic units (Peloponnese, Grece). Bull. Geol. Soc. Greece, 23/2, 515-530.

Photiades, A., in press. Revised geological map of Lygourio sheet in scale 1:50.000, Geological map of Greece, B'Edition. Institute of Geology and Mineral Exploration, Athens, Greece.

Photiades, A. and Karfakis, J., 1998. Tectonic evolution of Northern Argolis Peninsula (Greece). Third Intern. Conf. “Geology of the Eastern Mediterranean”, Nicosia, Cyprus, September 1998. Abstr., $p$. 53.

Photiades, A. and Keay, S., 2000. Mid-Late Jurassic granodiorite basement in southern Argolis Peninsula (Greece): tectonostratigraphic implications. In: Panayides, I., Xenophontos, C.\& Malpas, J. (eds), 2000, Proceedings of the Third International Conference on the Geology of the Eastern Mediterranean. Geol. Surv. Dpt. Cyprus, 233-239.

Photiades, A., Mitropoulos, D., in press. Revised geological map of Nafplion sheet in scale 1:50.000 , B'Edition. Institute of Geology and Mineral Exploration, Athens, Greece.

Photiades, A., Skourtsis-Coroneou, V., 1994. Stratigraphic and paleogeographic evolution of the Northern Argolis (Greece) during the Cretaceous - Paleogene. Bull. Geol. Soc. Greece, vol. XXX/2, 135-146.

Robertson, A.H.F. and Dixon, J.E., 1984. Introduction: aspects of the geological evolution of the Eastern Mediterranean. In: J.E. Dixon and A.H.F. Robertson (Eds.), The geological evolution of the Eastern Mediterranean. Geol. Soc. London Spec. Publ., 17: 1-74.

Robertson, A.H.F, Varnavas, S. and Panagos, A., 1987. Ocean ridge origin and tectonic setting of Mesozoic sulphide and oxide deposits of the Argolis Peninsula of the Peloponnesus, Greece. Sed. Geol., $53,1-32$.

Saccani, E., Padoa, E. and Photiades, A., 2004. Triassic mid-ocean ridge basalts from the Argolis Peninsula (Greece): new constraints for the early oceanization phases of the Neo-Tethyan Pindos basin. In Dilek Y. \& Robinson P. T. (eds). Ophiolites in Earth History, Geological Society of London Special Publication, vol.218, pp. 109-27.

Saccani, E. and Photiades, A., 2005. Petrogenesis and tectonomagmatic significance of volcanic and subvolcanic rocks in the Albanide-Hellenide ophiolitic mélanges. The Island Arc (2005) 14, 494-516. 
Sideris, C., Skounakis, St. and Simantov, J., 1987. Trace and REE geochemistry of a basic lava series from the Ermioni area (Argolis Peninsula, Greece). Ofioliti, 12/1, 107-112.

Süsskoch, H., 1967. Die Geologie der südöstlichen Argolis (Peloponnes, Griechenland). Diss. Univ. Marburg, Marburg.

Süsskoch, H., Bannert, D., Kalkreuth, W., Strauss, M., Jacobshagen, V., Fytikas, M., Innocenti, F. and Mazzuoli, R., 1984. Geological map of Greece in scale 1:50.000 "Methana sheet". Institute of Geology and Mineral Exploration, Athens, Greece.

Tataris, A., Kallergis, G., Kounis, G., Bizon, G. and Christodoulou, G., 1970. Nafplion sheet in scale 1:50.000, Geological map of Greece. Institute for Geology and Subsurface Research, Athens 1970, Greece.

Tsaila-Monopolis, S., Csaszar, G., Gaitanakis, P., Bodnar, E., Gorog, A. and Turnsek, D., 1992. Stratigraphy and sedimentary patterns of the Frachti hill , Argolis, Greece. In: Abstracts of $6^{\text {th }}$ Congress of the Geol. Soc. Greece, IGCP 262-Tethyan Cretaceous platform correlation, Athens, May 25-27, 1992, p.24.

Vrielynck, B., 1978. Données nouvelles sur les zones internes du Péloponnèse (Grèce). Thèse de $3^{e}$ cycle, Univ. de Lille, 137pp.

Vrielynck, B., 1980. Précisions sur la stratigraphie du Trias d'Argolide (Péloponnèse, Grèce) et conséquences structurales. Bull. Soc. géol. France, 22, 3, 345-352.

Vrielynck, B., 1982. Evolution paleogeographique et structurale de la presqu'ile d'Argolide (Grece). Revue de geologie dynamique et de geographie physique, 23(4), 277-288. 